\title{
РЕЦЕНЗІЯ \\ НА КОЛЕКТИВНУ МОНОГРАФІЮ «ОКУЛЬТНІ КОРЕНІ РЕЛІГІЄЗНАВСТВА: ПРО ВПЛИВ НЕ-ГЕГЕМОНІЧНИХ ТЕЧІЙ НА АКАДЕМІЧНЕ СЕРЕДОВИЩЕ БЛИЗЬКО 1900 РОКУ» (Berlin-Boston, De Gruyter, 2021)
}

\begin{abstract}
REVIEW
of the collective monograph "Occult Roots Of Religious Studies:

On The Influence Of Non-Hegemonic Currents On Academia

Around 1900" (Berlin-Boston, De Gruyter, 2021)
\end{abstract}

Колективна монографія Occult Roots of Religious Studies: On the Influence of Non-Hegemonic Currents on Academia around 1900 була опублікована видавництвом De Gruyter 8 червня 2021 року. За кілька місяців перед тим ії публікацію було анонсовано, і на цю подію з нетерпінням чекали дослідники західного езотеризму. Але насправді вона є корисною поживою для рефлексії релігієзнавців та істориків релігієзнавства, навіть якщо вони не займаються езотеричними предметами безпосередньо.

Книга присвячена важливій і не надто широко відомій темі з історії релігієзнавства, яка може виглядати навіть дещо скандальною, але насправді є цілком закономірною. Окультні корені релігієзнавчих студій - це гучна заява про те, що релігієзнавство поставало не лише 3 позитивістської чи християнської парадигми, але на його розвиток істотно вплинули течії, які в підзаголовку названі «не-гегемонічними». Редактори - Ів Мюлематтер та Гельмут Цандер пишуть про дві ключових тези, які покладені в основу кни- 
ги: 1) витоки релігієзнавства можна знайти в площині езотеризму; 2) езотеризм є невід'ємною частиною домінуючої культури, а не надбанням маргінальних і нечисельних закритих груп. На їхню думку, вплив езотеризму на становлення релігієзнавства дуже часто замовчується, хоча, починаючи ще від Макса Мюллера, який певний час щільно цікавився теософією, цей вплив нескладно простежити.

Езотеричні ідеї впливали на зацікавлення дослідника тантри Джона Вудроффа, тибетолога Снса Шлітера, дослідника кабали Гершома Шолема. Згодом езотеризм досліджували автори, які самі починали з захоплення відповідними ідеями - Антуан Февр, Кокку фон Штукрад. Ця тенденція існує і сьогодні, хоча мало хто з релігієзнавців говорить про свій езотеричний бекграунд відкрито. Не прийнято було про це писати й раніше, але деякі притаманні окультизму XIX століття ідеї увійшли в релігієзнавство першої половини XX століття, приміром, еволюціонізм, прагнення поєднати науку і релігію, знайти універсальні спільні риси в різних релігіях тощо. А оскільки автори не часто згадували власні езотеричні (окультні) зацікавлення в текстах, про цей предмет можуть більше сказати їхні власні біографії. Тому один з розділів книги присвячений саме біографіям відомих релігієзнавців, які мали інтерес до окультизму, перш за все, до Теософського чи Антропософського товариств, а також до масонства, переніалізму, мартінізму тощо. Власне, біографічним довідкам присвячено сс.239-267, і там згадані не лише ті автори, про яких є окремі розділи книги, а й інші відомі релігіє-знавці з езотеричним бекграундом.

Починається книга 3 грунтовної статті Гельмута Цандера, де автор (і один зі співредакторів) окреслює межі предмету езотеризму як такого. Як пише Цандер, існують 
численні визначення езотеризму, які поставали в дослідженні релігій ще від XIX століття, а сам термін навіть раніше вживався практиками негегемонічних духовних напрямів. До того ж, паралельно до терміну «езотеризм» приблизно той самий комплекс явищ часто називають окультизмом чи герметизмом, що ще більш ускладнює пошук уніфікованого визначення. «Окультизм» як термін частіше співвідноситься з модерними езотеричними рухами, які намагалися поєднати в собі науку та релігію чи духовні практики, тоді як «герметизм» стосується, перш за все, традиції, яка сягає неоплатонізму. Натомість специфічних рис такого штибу для езотеризму немає, тому він є більш об'ємним і більш розмитим поняттям. Понад те, сучасні дослідники взагалі можуть ставитися до езотеризму як поняття дискурсивного (залежного від позиції конкрет-ного адепта чи дослідника) і навіть порожнього. Ситуація ще більш ускладнюється тим, що дослідження західного езотеризму мало поширюються за межі свого мовного середовища, приміром, ім'я навіть А. Февра мало відоме в німецькомовній науці, тоді як для франкомовної він є класиком. Цандер зупиняється також і на тренді останніх років - відкидання прикметника «західний», коли езотеризм починає досліджуватися як універсальна категорія, не пов'язана лише 3 неоплатонічною традицією чи Західною Свропою. Таким чином, відкидаючи прикметник «західний», науковці стали перед проблемою, а що ж тепер взагалі позначає іменник «езотеризм», і як його накладати на різні духовні практики й традиції. I замість того, аби намагатися все ж втиснути будь-які прояви езотеричного з різних традицій у єдине визначення, автор іде більш зрозумілим шляхом та залишає поняття «езотеричного» відкритим, таким що потребує конкретизації у кожному окремому дослідженні. 
Рецензія на колективну монографію «Окультні корені...»...

Наступні розділи присвячені різним відомим науковцям, починаючи від директора Академії природничих наук «Леопольдіна» Християна Неєса фон Езенбека, що цікавився протягом свого життя магнетизмом і спіритуалістичними вправами. Далі йдуть розділи, присвячені езотеричним захопленням перекладача «Тибетської книги мертвих» Вальтера Еванса-Вентца; одного з перших дослідників тантри Джона Вудроффа, який також цікавився індійським езотеризмом як практик; відомого дослідника кабали Гершома Шолема, який поділяв чимало теософських поглядів, хоча й відмежовувався від Теософського товариства Олени Блаватської; представника компаративного релігієзнавства Поля Массона-Урселя, який виходив з позицій перенніалізму (визнання наявності єдиної езотеричної мудрості в різних релігіях); відомого археолога і водночас послідовника антропософії Вальтера Андрее.

Інші розділи присвячені більш широким колам авторів чи питань, приміром, у розділі «The Science of Religion, Folklore Studies, and the Occult Field in Great Britain (1870-1914): Some Observations on Competition and Cain-Abel Conflicts» Марко Френшковскі звертається до британських фольклористів, етнографів і релігієзнавців - Едварда Ленга, Едварда Тайлора та інших, які не завжди погоджувалися з езотеричними уявленнями окультистів свого часу, але принаймні рефлексували щодо цього. Так, автор наводить щоденникові дописи класика релігієзнавства Е.Тайлора за 1872 рік, де той пише про відвідування спіритичних сеансів та своє зацікавлення в психічних феноменах, яке, втім, не підкріпилося достатніми доказами, після яких він міг би повірити в дієвість спіритизму як практики. Так само езотеризм (точніше - магія) був одним з ключових предметів зацікавлення Джеймса Фрезера, який навіть у друго- 
му виданні змінив назву своєї ключової праці з «Золота гілка: дослідження 3 порівняльного релігієзнавства» (1890) на «Золота гілка: дослідження магії та релігії (1900).

Окрема стаття «Academic Study of Kabbalah and Occultist Kabbalah» Боаза Хусса присвячена різним підходам до вивчення кабали - академічному та окультному. Автор зосереджується на постаті Гершома Шолема, який хоча й негативно ставився до сучасних йому окультистів-кабалістів, а втім був лояльнішим до більш ранньої християнської кабали. Натомість саме ідеї окультистів щодо кабали як вічної та універсальної мудрості, єдиної з езотеричними вченнями різних традицій, вплинули не лише на розуміння кабали в нью-ейдж, але також і в деяких сучасних єврейських нео-кабалістичних рухах. Окрім Гершома Шолема автор також розглядає творчість Адольфа Франка найбільш яскравого попередника Шолема. Франк цікавився також іншими езотеричними напрямами, написав праці, присвячені Парацельсу, Луї-Клоду де Сен-Мартену, Мартінесу де Паскуаллі, широко цитував тогочасні періодичні теософські, мартіністські видання в своїх роботах.

Б.Хусс пише також про одного 3 небагатьох представників Східної Свропи в цій монографії - румунського дослідника кабали та езотеризму в більш широкому сенсі Мойсея Гастера, який, втім, ще в 1885 році змушений був залишити батьківщину й переїхати до Великобританії через свою активну участь у сіоністському русі. Загалом варто зазначити, що брак інформації про східноєвропейські кейси є одним з найбільших недоліків видання - переважна більшість згаданих тут авторів працювали на Заході. Навіть ще один румунський релігієзнавець Мірча Еліаде, який так само, як і А.Февр, був прихильником перенніалізму та присвятив чимало уваги дослідженню езотеризму, в книзі 
Рецензія на колективну монографію «Окультні корені...»...

згаданий лише побіжно. Взагалі не приділено уваги відомим російськомовним авторам, таким як буддологи Ісаак Шмідт і Федір Щербатськой, перекладач «І-Цзін» Юліан Щуцький, тибетолог Юрій Реріх (син відомого подружжя Миколи та Олени Реріхів), інтерес яких до західного езотеризму був не менший, ніж у численних представлених у книзі західних релігієзнавців. Понад те, варто вказати, що і наукове дослідження езотеризму на пострадянському просторі починалося, значною мірою, з ініціативи сходознавців, які продовжили школу згаданих вище дослідників, i тому пострадянські дослідники легко уникли проблеми глобалізації езотеризму й відмови від прикметника «західний», які стали справжнім викликом для науковців 3 західноєвропейських університетів, адже від початку зверталися до езотеризму крізь призму східних езотеричних течій. Однією з небагатьох умовно східноєвропейських постатей, чиї біографії присутні в книзі, є Анна Каменська, яка була народжена в Російській імперії, але не жила там від раннього дитинства, а ії наукова кар'єра, більшою мірою, була пов' язана зі Швейцарією.

Загалом книга є непересічною, і можна навіть казати про те, що ініціатори ії видання претендують на нове слово в історії релігієзнавства та намагаються максимально широко донести свою думку. Зокрема, про це свідчить і той факт, що книгу одразу було викладено у вільний доступ на сайті видавництва, що є дуже важливим кроком у контексті сучасних цін на західні академічні видання. Попри певні недоліки, пов'язані 3 нерівномірним охопленням різних регіонів і тематичних напрямів (більша увага в книзі присвячена Західній Європі та теософії, відповідно), монографія є дуже важливою та вводить в науковий дискурс раніше маловідомі факти про зацікавлення відомих релігієзнавців 
Українське релігієзнавство № 94

початку XX століття езотеризмом і вплив цих зацікавлень на їхні наукові студії. Безумовно, такий підхід є корисним для повнішого розуміння історії релігієзнавчої думки та може бути застосований і до інших дослідників релігії, зокрема, українських.

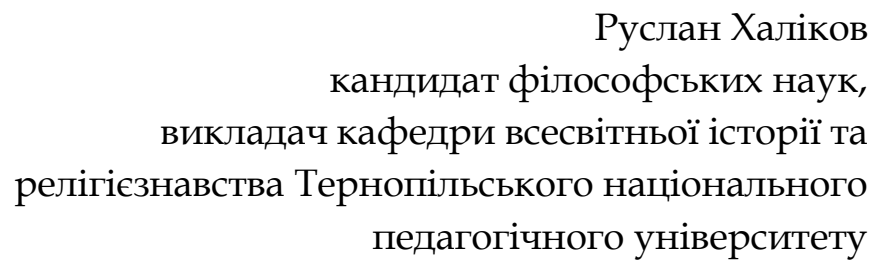

